\title{
STUDY ON AXIAL COMPRESSION BEARING CAPACITY OF REINFORCED CONCRETE FILLED STEEL TUBE MEMBERS
}

\author{
Xiao-Xiong Zha*, Xiao-Li Li, Ning Wang and Cheng-Yong Wan \\ Shenzhen Graduate School, Harbin Institute of Technology, Shenzhen 518055, China \\ *(Corresponding author: E-mail: Zhaxx@hit.edu.cn)
}

Received: 30 May 2014; Revised: 30 January 2015; Accepted: 25 June 2015

\begin{abstract}
The bearing capacity equation of reinforced concrete filled steel tube (RCFST) members under axial loads is derived by using the combined unified and limit equilibrium theories. The concrete strength increase due to the constraint effect of the steel tube is taken into account through the use of unified theory; whereas the concrete strength increase due to the constraint effect of the stirrups is considered through the use of the limit equilibrium theory. Three-dimensional nonlinear finite element analysis and experimental tests were carried out and the corresponding results are reported in this paper. The comparisons of the numerical, experimental and theoretical results show that there are in good agreement between these three different methods. However, the present theoretical analysis model is not only simple and convenient to use but also consistent with existing Chinese design codes for CFST columns.
\end{abstract}

Keywords: Reinforced concrete filled steel tube, Axial compression bearing capacity, Unified theory, Limit equilibrium theory, Finite element

DOI: 10.18057/IJASC.2016.12.2.2

\section{INTRODUCTION}

Because of many advantages, concrete filled steel tubes (CFST) are very popular in high rise buildings, bridges and offshore structures. Extensive studies have been conducted on the static and dynamic analyses, and the fire performance of CFST members [1-10]. For example, Han et al. [1], Yu et al. [2], Dundu et al. [3], Dai et al. [4] studied the compressive strength of CFST members. Han et al. [1], Yu et al. [5], Prabhu et al. [6] investigated the axial compression performance of CFST members encased by various different materials, such as concrete, FRP and CFRP. Wang et al. [7] studied the behavior of fire-exposed CFST columns. More recently, Ma et al. [8] studied their seismic behavior of CFST columns. Based on these studies, Chinese Codes [11] for design of concrete filled steel tubular members has been developed in 2014.

A RCFST member is formed by filling a steel tube with reinforcement concrete. Because of the large size of the section the RCFST members may have smaller thickness of steel tube than CFST members, which can cause trouble in machining, construction and welding. Reinforced concrete filled steel tubes (RCFST) have been used in multi-story buildings, particularly, high-level buildings. Figure 1 shows a typical section of a steel tube column and the corresponding column layout of Shenzhen Jingji financial center, which is ranked as the tenth highest building in the world.

Some studies have been conducted on the static performance of RCFST columns [12-20]. Lie [14] gave the resistance of circular steel columns filled with bar-reinforced concrete. Chang et al. [15] and Zhu et al. [16] conducted experimental studies on the performance of steel-reinforced concrete-filled-steel tubular members. Wang et al. [18] studied on experimental performance twin-column RCFT pier. Endo et al. [19] and Xiamuxi et al. [20] obtained the evaluation for axial 
compressive strength of RCFST columns and the results were validated using experimental data. But most studies on the mechanical properties at room temperature didn't consider the constraints of the stirrup on core concrete. And they just simply considered the superposition of steel tube, concrete and longitudinal reinforcement on the basis of a coefficient, not considering the synergy of steel tube and concrete.

\begin{tabular}{|c|c|c|c|}
\hline \multicolumn{4}{|c|}{ Notations } \\
\hline $\mathrm{K}$ & $\begin{array}{l}\text { Lateral constant determined by tests, } \\
K=4 \text { usually }\end{array}$ & $A_{c o r}$ & $\begin{array}{l}\text { Area of concrete confined by stirrups, } \\
A_{\text {cor }}=\pi d_{s}^{2} / 4\end{array}$ \\
\hline$f_{c k}^{\prime}$ & $\begin{array}{l}\text { Axial compressive strength of concrete } \\
\text { confined by concrete stirrup }\end{array}$ & $f, f_{c}$ & $\begin{array}{l}\text { Design strength of steel and concrete, } \\
\text { respectively }\end{array}$ \\
\hline$f_{r}$ & $\begin{array}{l}\text { Lateral pressure on concrete surrounded by } \\
\text { stirrups }\end{array}$ & $\theta^{*}$ & $\begin{array}{l}\text { Equivalent confining factor of multilayer } \\
\text { stirrups }\end{array}$ \\
\hline$A_{s s 1}$ & Area of single-layer stirrup & $\alpha$ & Steel ratio \\
\hline$f_{y v}$ & Tensile strength of stirrup & $\psi$ & Hollow ratio, $\psi=A_{h} /\left(A_{c}+A_{h}\right)$ \\
\hline$d_{s}$ & $\begin{array}{l}\text { Ddiameter of concrete column surrounded } \\
\text { by stirrups }\end{array}$ & $f_{y}, f_{c k}$ & $\begin{array}{l}\text { Characteristic strength of steel and } \\
\text { concrete, respectively }\end{array}$ \\
\hline$S$ & Spacing of stirrups & $B, C$ & Parameters according to section types \\
\hline$A_{\text {sso }}$ & $\begin{array}{l}\text { Equivalent reinforcement area of stirrup, } \\
A_{\text {sso }}=\frac{\pi d_{s} A_{s s 1}}{s}\end{array}$ & $\theta_{h}$ & $\begin{array}{l}\text { Standard value of confining factor, } \\
\theta_{h}=\alpha_{0} f_{y} /\left(1.1 f_{c k}\right)\end{array}$ \\
\hline$A_{c}, A_{h}$ & $\begin{array}{l}\text { Area of concrete and hollow part in } \\
\text { HCFST, respectively }\end{array}$ & \multirow[t]{3}{*}{$\theta, \theta_{1}$} & \multirow{3}{*}{$\begin{array}{l}\text { Confining factor of steel tube in CFST } \\
\text { and RCFST respectively, and } \\
\theta=\frac{A_{s} f_{y}}{A_{c} f_{c k}}, \quad \theta_{1}=\frac{A_{s} f_{y}}{A_{c} f_{c k}^{*}}\end{array}$} \\
\hline$A_{c}, A_{s}$ & Area of concrete and steel tube & & \\
\hline$\rho_{v}$ & Stirrup ratio & & \\
\hline$f_{s c,}, f_{s c}$ & $\begin{array}{l}\text { Combined strength of CFST and RCFST, } \\
\text { respectively }\end{array}$ & $A_{s c}$ & Total area of RCFST, $\mathrm{Asc}=\mathrm{As}+\mathrm{Ac}$ \\
\hline$A_{b}$ & Total area of reinforcement in RCFST & $f_{b}$ & $\begin{array}{l}\text { Yield strength of reinforcement in } \\
\text { RCFST }\end{array}$ \\
\hline
\end{tabular}

In this paper the behavior of RCFST members under axial compression bearing capacity is studied through the theoretical analysis, finite element simulation and experimental tests. A theoretical analysis model is developed by using the combined unified and limit equilibrium theories. The present theoretical analysis model is not only simple and convenient to use but also consistent with existing Chinese design codes [11] for CFST columns. 

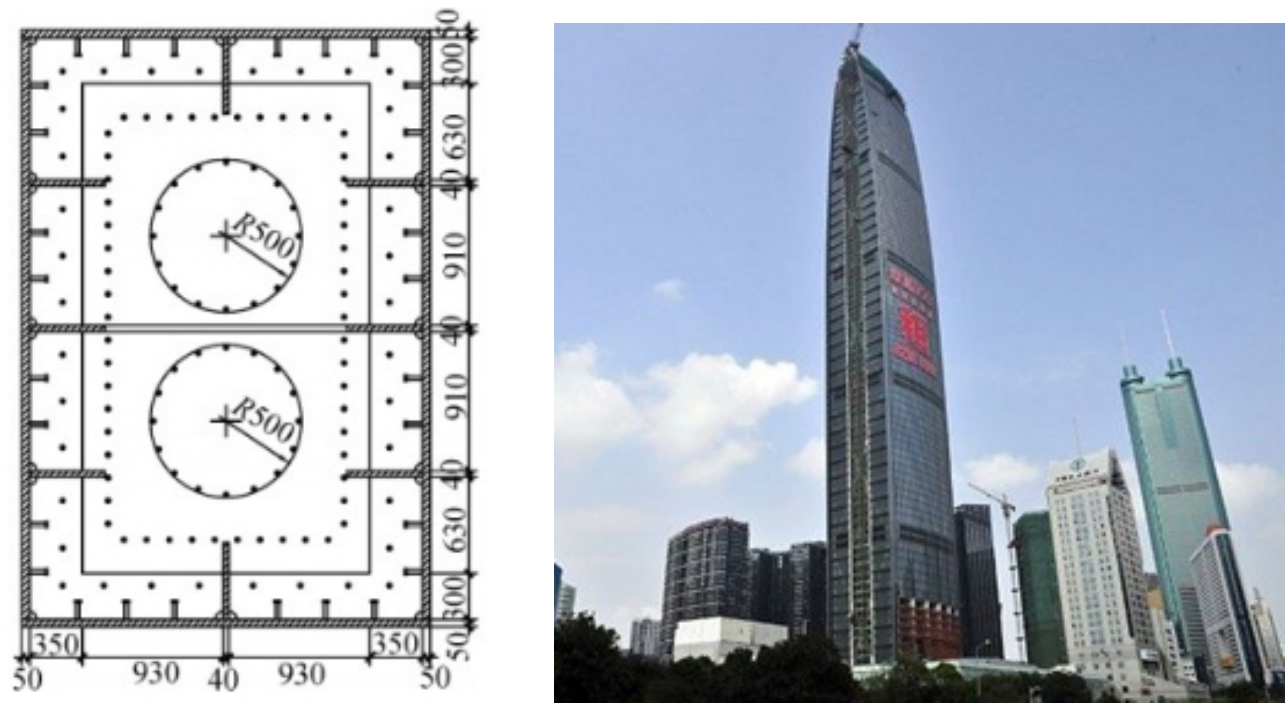

Figure 1. Typical Section of Steel Tube Column and Building Elevation of King Key Financial Center

\section{THEORETICAL DERIVATION OF RCFST MEMBERS}

In general, the concrete in RCFST is restrained by both the outside steel tube and inside stirrups as shown in Figure 2. The constraints will enhance the concrete compressive strength, which will be discussed separately in the following analyses.

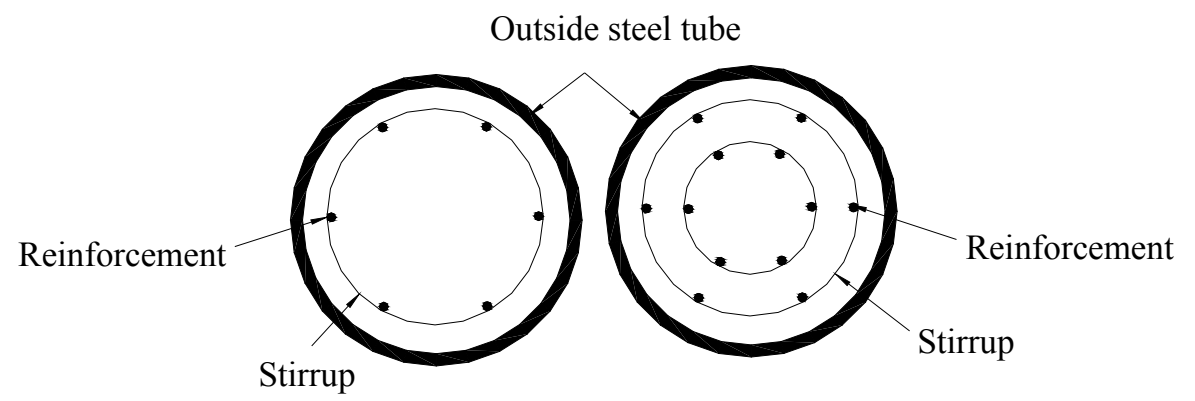

a) Single-layer reinforcement section b) Multilayer reinforcement section

Figure 2. Cross Section Diagram of RCFST

\subsection{The Equivalent Strength of Core Concrete from Stirrups}

According to the configuration of the reinforcement, the core concrete of a RCFST member can be treated as a single layer material or a multilayer material, as shown in Figure 3. Both cases will be discussed in this paper. The equivalent strengths of the core concrete in both cases are to be developed. 
The first layer stirrup
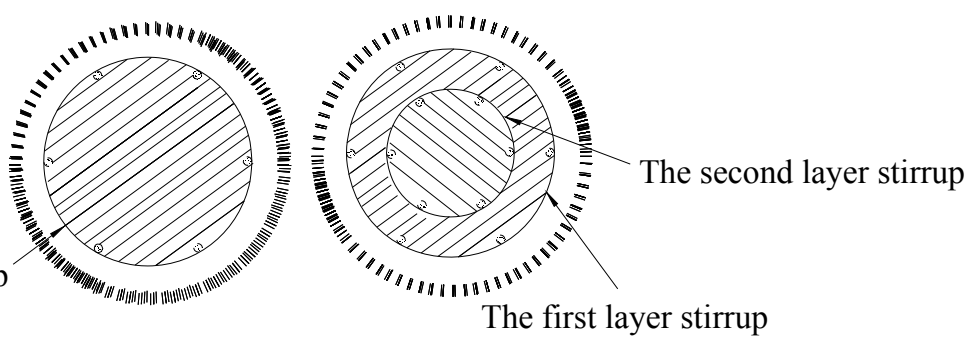

a) Single-layer reinforcement section $\quad$ b) Multilayer reinforcement section Figure 3. Core Concrete Confined by Stirrups diagram of RCFST

\subsubsection{The compressive strength of concrete confined by stirrups}

\section{(1) Axial compressive strength of concrete confined by single-layer stirrups}

According to limit equilibrium theory from the theory of reinforcement concrete, if the spacing of spiral stirrups or welded stirrups is not larger than $80 \mathrm{~mm}$ and $d_{s} / 5$ (where $d_{s}$ is the diameter of the concrete column surrounded by stirrups), the strength improvement of core concrete due to the effect of stirrups should be considered (Slater et al. [21]), as shown in Figure 4.

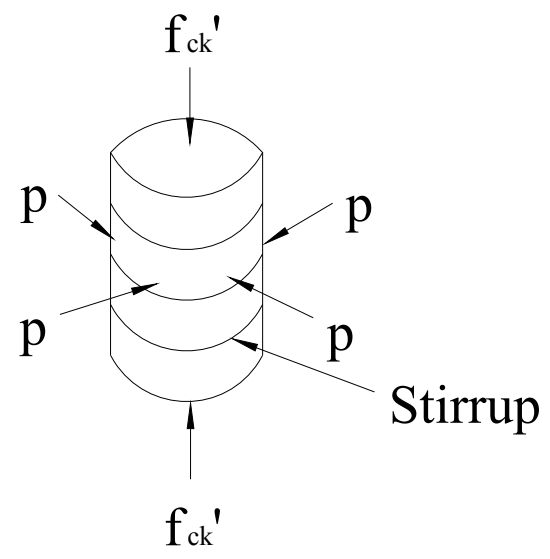

Figure 4. Concrete under Three-way Pressure

In this case, the longitudinal compressive strength of concrete confined by stirrups can be determined as follows:

$$
\begin{aligned}
& f_{c k}^{\prime}=f_{c k}+K f_{r} \\
& f_{r}=\frac{2 A_{s s 1} f_{y v}}{d_{s} s}
\end{aligned}
$$

According to Eqs. 1, 2 and in general the lateral constraint coefficient is taken as $K=4$, it yields

$$
f_{c k}^{\prime}=f_{c k}\left(1+\frac{2 A_{s s 0}}{A_{c o r}} \cdot \frac{f_{y v}}{f_{c k}}\right)
$$


Assuming $\rho_{v}$ is the stirrup reinforcement ratio, the confining factor of steel tube $\theta$ can be defined as follows

$$
\theta=\rho_{v} \cdot \frac{f_{y v}}{f_{c k}}
$$

So the axial compressive strength of the confined single-layer concrete stirrup can be expressed as:

$$
f_{c k}^{\prime}=f_{c k}(1+2 \theta)
$$

\section{(2) Axial compressive strength of concrete confined by multilayer stirrups}

Concrete in a RCFST column of multilayer stirrups can be divided into $i+1$ parts, as the shadow part shown in Figure 3 (b). As far as the whole member is concerned, the effects of individual layer stirrups on the concrete can be calculated using a superposition method. Hence, the ferrule effect increases gradually from outside to inside.

Assuming that $A_{c i}$ is the area divided by the $i$ th and (i+1)-th layer stirrups, $\theta_{i}$ is the ferrule coefficient of the $i$ th layer stirrups, $A_{\text {ssoi }}$ is the equivalent reinforcement area of the $i$ th layer stirrups, $\rho_{v}$ is the stirrup ratio, and $f_{c k i}$ is the concrete strength restrained by the $i$ th layer stirrup, Eq. 4 can be expressed as follows

$\theta_{i}=\rho_{v} \cdot \frac{f_{y v}}{f_{c k}}=\frac{A_{s s o i}}{A_{c i}} \cdot \frac{f_{y v}}{f_{c k}}$

when $i=1, \quad f_{c k i}=f_{c k}\left(1+2 \theta_{1}\right)$

when $i>1, \quad f_{c k i}=f_{c k}\left(1+2 \sum_{k=1}^{i} \theta_{k}\right)$

According to the above formulas, the compressive strength of concrete confined by the multilayer stirrups is equal to the ordinary concrete strength multiplied a stirrup enhancement coefficient.

\subsubsection{Equivalent strength of core concrete within the outside steel tube}

The total bearing capacity of concrete within the steel tube including plain concrete with no stirrups and the concrete confined by stirrups can be given by Eq. 9 , including the shadow and blank parts shown in Figure 3.

$$
N_{c}=A_{c} f_{c k}+\sum_{i+1}^{n} A_{c i}\left(f_{c k i}-f_{c k i-1}\right)=A_{c} f_{c k}+2 \sum_{i=1}^{n} A_{c i} f_{c k} \theta_{i}
$$

Substituting Eq. (6) into (9), it yields

$$
N_{c}=A_{c} f_{c k}+2 \sum_{i=1}^{n} A_{c i} f_{c k} \frac{A_{s s o i}}{A_{c i}} \cdot \frac{f_{y v}}{f_{c k}}=A_{c} f_{c k}+2 f_{y v} \sum_{i=1}^{n} A_{s s o i}=A_{c} f_{c k}\left(1+2 \theta^{*}\right)
$$

Since 
$\theta^{*}=\frac{f_{y v} \sum_{i=1}^{n} A_{s s o i}}{A_{c} f_{c k}}$

Eq. 10 is simplified as follows

$f_{c k}^{*}=\frac{N_{c}}{A_{c}}=f_{c k}\left(1+2 \theta^{*}\right)$

\subsection{Axial Compression Bearing Capacity of RCFST by steel tube}

\subsubsection{Combined strength by steel tube}

According to the CFST "unified theory" [13], the compressive strength of the CFST column can be expressed as follows:

$f_{s c}=\left(1.212+B \xi+C \xi^{2}\right) f_{c k}$

The strength of concrete in Eq. 12 replacing 13, we have the formula of the combined strength of RCFST columns:

$f_{s c}^{\prime}=\left(1.212+B_{1} \xi_{1}+C_{1} \xi_{1}^{2}\right) f_{c k}^{*}=\left(1.212+B_{1} \xi_{1}+C_{1} \xi_{1}^{2}\right) f_{c k}\left(1+2 \theta^{*}\right)$

where, $\quad \xi_{1}=\frac{A_{s} f_{y}}{A_{c} f_{c k}^{*}} \quad, \quad B=B_{1}=0.1759 \frac{f_{y}}{235}+0.974 \quad, \quad C=-0.1038 \frac{f_{c k}}{20.1}+0.0309 \quad$ and $C_{1}=-0.1038 \frac{f_{c k}^{*}}{20.1}+0.0309$.

\subsubsection{Axial compression bearing capacity}

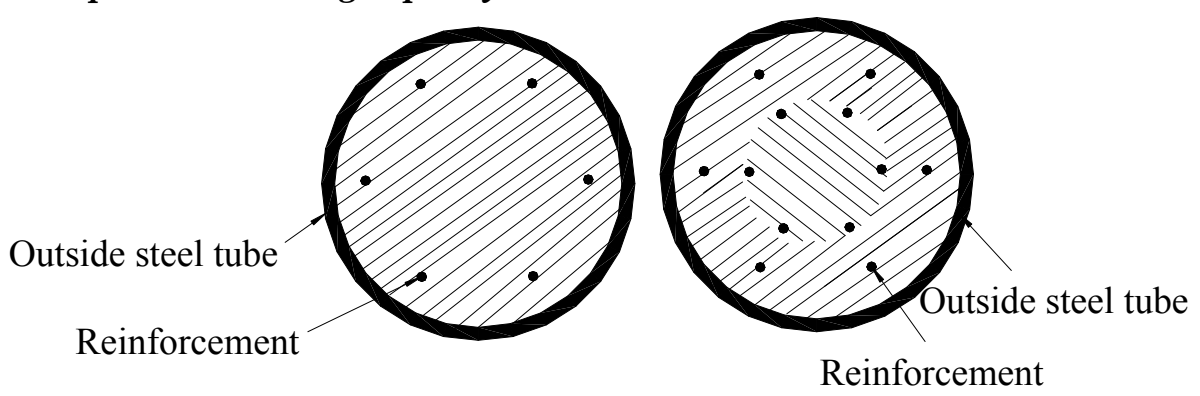

Figure 5. Cross Section Diagram of RCFST without Stirrup

According to superposition principle, the axial compression bearing capacity of RCFST members is obtained by the sum of the axial compression bearing capacity of longitudinal bar and CFST members confined by stirrups, as shown in Figure 5.

$N_{s c b}=A_{s c} f_{s c}^{\prime}+A_{b} f_{b}=A_{s c}\left(1.212+B_{1} \xi_{1}+C_{1} \xi_{1}^{2}\right) f_{c k}\left(1+2 \theta^{*}\right)+A_{b} f_{b}$ 
The above description demonstrates that the axial compression bearing capacity of RCFST members is related to the ferrule coefficient of stirrups and steel tube, reinforcement ratio and strength of longitudinal reinforcement. If the ferrule coefficient or the reinforcement ratio becomes higher, the overall load-bearing capacity becomes stronger.

\subsubsection{Compared with the formula of national code when it is CFST}

When the reinforcement ratio is zero, the RCFST reduces to the CFST. Because $A_{b}=0$ and $\theta^{*}=0$, Eq. 15 is simplified into Eq. 16.

$$
\begin{aligned}
& N_{s c b}=A_{s c} f_{s c}^{\prime}+A_{b} f_{b} \\
& =A_{s c}\left(1.212+B_{1} \xi_{1}+C_{1} \xi_{1}^{2}\right) f_{c k} \\
& =A_{s c}\left(1.212+B \xi+C \xi^{2}\right) f_{c k} \\
& =A_{s c} f_{s c}
\end{aligned}
$$

By comparing Eqs. 13 and 16, it can be seen that the formula of RCFST is in a good agreement with the formula recommended in Chinese design code for CFST members. Furthermore Eq. 15 can be regarded as an extension of the Chinese national design code for RCFST members.

\section{FINITE ELEMENT SIMULATION OF RCFST MEMBERS}

\subsection{The material constitutive relation}

Core concrete of RCFST is simulated by using the plastic-damage constitutive model (Ludovic et al. [22]). The uniaxial compressive stress-strain model of concrete is utilized as suggested by Hognestad (Jeffrey et al. [23]), which is simplified as the elastic-perfectly plastic model, as shown in Figure 6. Tensile in elastic part is similar with compressive parts, and the ultimate tensile strength is taken as one-tenth of the compressive strength. The steel model uses the bilinear model. Poisson's ratio is taken as 0.25 for concrete and 0.3 for steel.
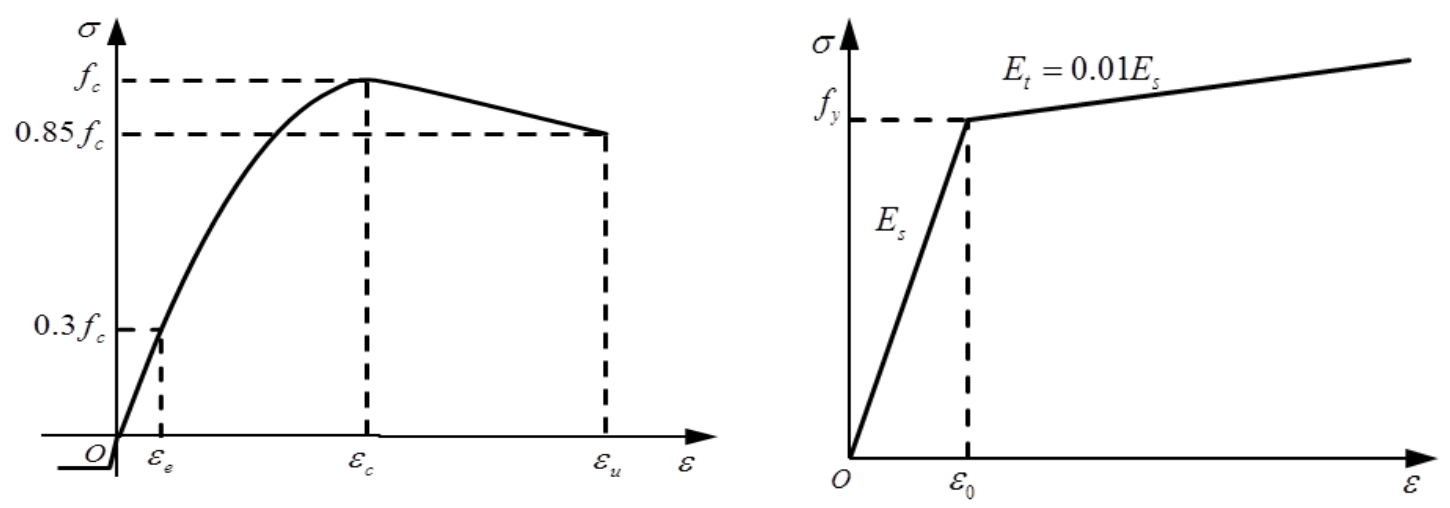

Figure 6. The Constitutive Relation of Concrete and Steel

\subsection{The Finite Element Model}

The three-dimensional solid element (C3D8R) is used to simulate the core concrete and steel tube of CFST members ( $\mathrm{Lu}$ and Zhao [24]). The truss element (T3D2) is adopted to simulate the 
unidirectional reinforced bars. For the convenience of applying boundary conditions, two rigid circular plates are used in the finite element analysis (FEA) model to simulate the upper and lower cover plates of the CFST member. All boundary conditions and loads are directly loaded on the rigid plates. Reinforced skeleton frame and concrete are contacted by using the Embedded region defined in ABAQUS. Element meshes of core concrete and reinforcement are shown in Figure7.
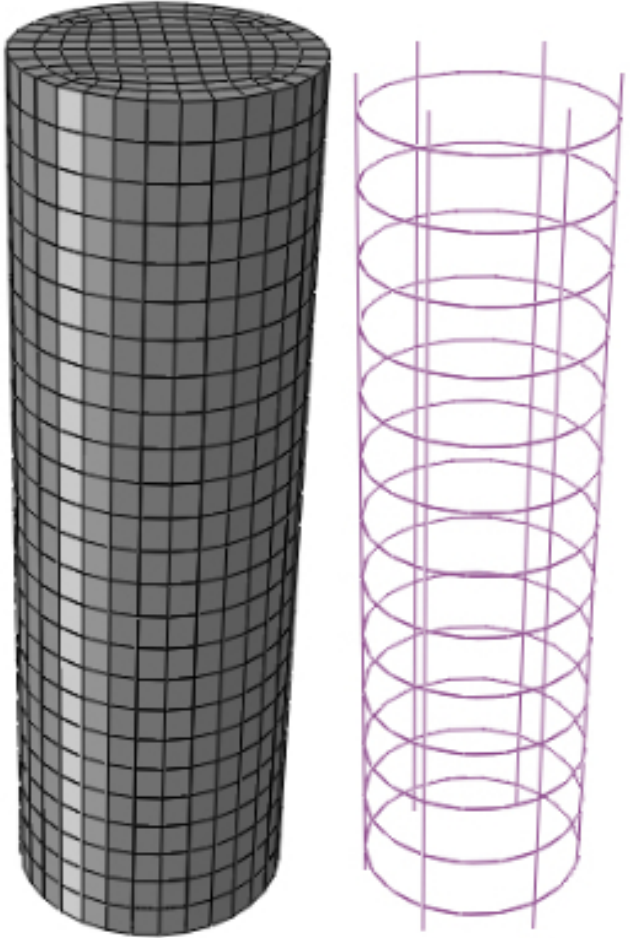

Figure 7. Model Meshes of Core Concrete and Reinforcement

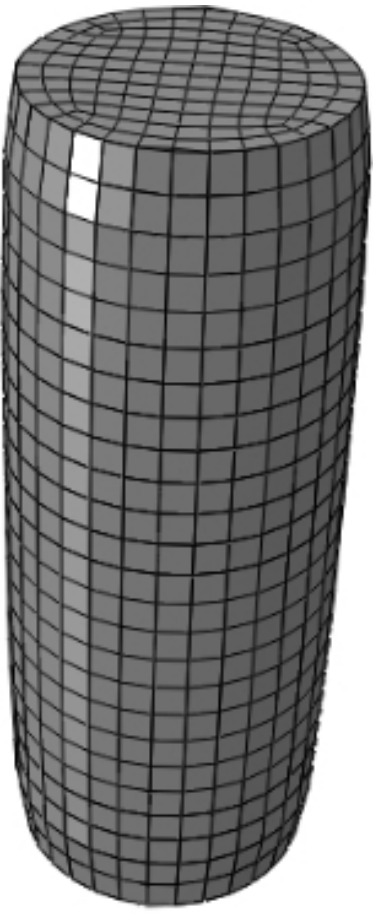

Figure 8. Deformation Model

Fixed displacement constraints are imposed to the bottom rigid plate. On the top rigid plate all other degrees of freedom except for the axial displacement are fixed. The axial loading is added on the center of the top plate. The problem is solved by using the displacement loading method.

\subsection{Finite Element Results}

Before the parametric analysis of the finite element analysis, finite element model is verified in this section. From the comparison between finite element simulation and its theoretical value under different parameters, it is found finite element value is slightly higher than the theoretical value, but the error is very small. Figure 8 plots a typical deformed shape of the RCFST column.

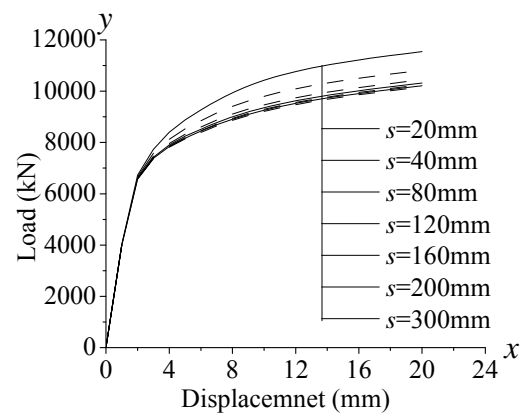

Figure 9. The Influence of Stirrup Spacing for Load-displacement Curve 
Figure 9 shows the influence of the number of stirrups on the ultimate bearing capacity of the RCFST column (Wang [25]). It can be seen from the figure that the ultimate load increases with the decrease of the spacing of the stirrups. Table 1 gives a comparison of the finite element results with the theoretical values. Through the parameter analysis, it is found that the influence of the steel tube ferrule coefficient and slenderness ratio on the load-displacement curve of RCFST members are similar to CFST members.

According to the results of finite element simulation, reinforcement ratio, the strength of longitudinal reinforcement and the stirrup spacing are the key parameters, which should be considered in the experimental tests.

Table 1. Partial Value of Finite Element Simulation Compared with the Theoretical Value

\begin{tabular}{|c|c|c|c|c|c|c|c|c|}
\hline $\begin{array}{c}\text { Steel } \\
\text { ratio } \\
\alpha\end{array}$ & $\begin{array}{c}\text { Steel pipe } \\
\text { intensity } \\
f_{y}(\mathrm{MPa})\end{array}$ & $\begin{array}{c}\text { Concrete } \\
\text { strength } \\
f_{c k}(\mathrm{MPa})\end{array}$ & $\begin{array}{c}\text { Reinforcement } \\
\text { ratio } \\
\rho_{b}\end{array}$ & $\begin{array}{c}\text { Longitudinal } \\
\text { reinforceme } \\
\text { nt intensity } \\
f_{b}(\mathrm{MPa})\end{array}$ & $\begin{array}{c}\text { Stirrup } \\
\text { spacing } \\
S(\mathrm{~mm})\end{array}$ & $\begin{array}{c}\text { Theoretical } \\
\text { value } \\
N_{c}(\mathrm{kN})\end{array}$ & $\begin{array}{c}\text { Simulation } \\
\text { value } \\
N_{0}(\mathrm{kN})\end{array}$ & $N_{0} / N_{c}$ \\
\hline 0.080 & 235 & 33.5 & 0.027 & 335 & 80 & 9455 & 9757 & 1.032 \\
\hline 0.080 & 235 & 40.2 & 0.027 & 335 & 80 & 10489 & 10732 & 1.023 \\
\hline 0.080 & 235 & 46.9 & 0.027 & 335 & 80 & 11526 & 11657 & 1.011 \\
\hline 0.080 & 345 & 20.1 & 0.027 & 335 & 80 & 8825 & 9039 & 1.024 \\
\hline 0.080 & 390 & 20.1 & 0.027 & 335 & 80 & 9443 & 9581 & 1.015 \\
\hline 0.080 & 420 & 20.1 & 0.027 & 335 & 80 & 9865 & 9942 & 1.008 \\
\hline 0.019 & 235 & 20.1 & 0.027 & 335 & 80 & 5631 & 5598 & 0.994 \\
\hline 0.039 & 235 & 20.1 & 0.027 & 335 & 80 & 6248 & 6367 & 1.019 \\
\hline 0.059 & 235 & 20.1 & 0.027 & 335 & 80 & 6837 & 7066 & 1.034 \\
\hline & & & & & & & & 1.028 \\
\hline
\end{tabular}

\section{AXIAL COMPRESSION TEST RESEARCH}

\subsection{General Situation of Test}

\subsubsection{Material}

Tensile tests of reinforcement and steel tube were carried out by using hydraulic universal material testing machine. The sample size was determined according to the tensile test of metallic materials. The length of reinforcement specimens is $500 \mathrm{~mm}$. Figure 10 shows some of the specimens tested for the steel tube and reinforcement. The specimens tested for concrete is shown in Figure 11 (Wang [25]), which is the standard cubic specimen of $150 * 150 * 150 \mathrm{~mm}$.

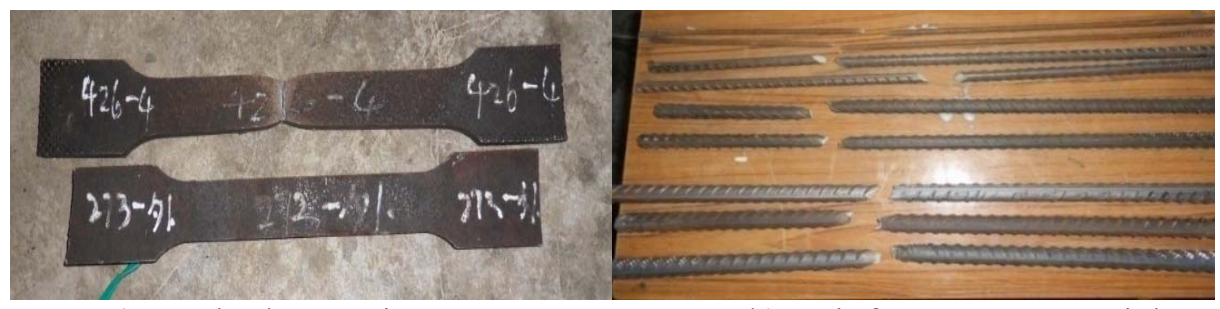

a) Steel tube specimens

b) Reinforcement material specimens

Figure 10. Steel Specimens 


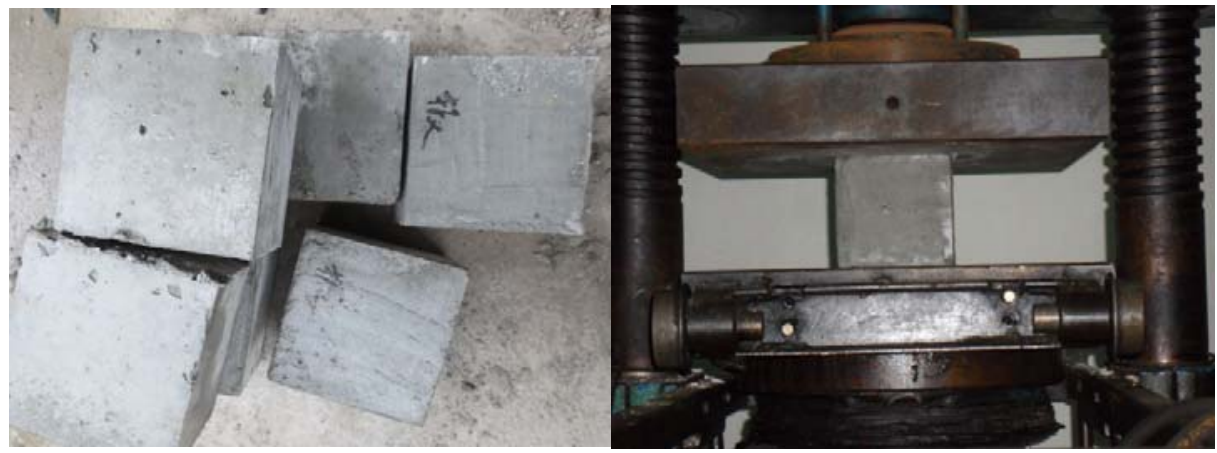

Figure 11. Concrete Standard Cube Specimens

The yield and ultimate strengths for the steel were obtained in the steel tensile tests, which show that both the steel tube and reinforcement have very good ductility. The concrete cubic compressive strength $f_{c k}$ is used to calculate the compressive strength of the prism by using : $f_{c k}=k_{2} f_{c u, k}^{150}$ (where $k_{2}$ is the conversion factor, for ordinary strength concrete, $k_{2}=0.67$ ).

\subsubsection{Specimens}

The axial compressive tests included CFST specimens and RCFST specimens, and all steel tubes were of the same size. RCFST specimens were divided into three groups according to the strength of internal longitudinal reinforcement, and there were three kinds of longitudinal reinforcement ratios and two stirrup spacings in each group specimens. The section size of the cover plates was $500 \mathrm{~mm} \times 500 \mathrm{~mm}$, with an identical thickness of $16 \mathrm{~mm}$. All parameters of specimens are listed in Table 2 .

The experiment was carried out in architecture lab of South China University of Technology. The specimens were made by the procedure: (1) fabrication of steel reinforcement cage, (2) welding reinforcement to the bottom plate, (3) welding steel tube to the bottom plate, (4) pouring concrete into the steel tube. During the casting of concrete, a $50 \mathrm{~mm}$ plug-in vibrator was used to vibrate the concrete. After the concrete is casted, the specimen was cured for 12 hours in an environment with fixed temperature and humidity conditions. After the concrete was cured, the top steel plate was welded to the specimen (Jamaluddin et al. [26]).

Table 2. Parameters of the Specimens under Axial Compression

\begin{tabular}{|c|c|c|c|c|c|c|c|c|c|}
\hline Sample number & $D(\mathrm{~mm})$ & $t(\mathrm{~mm})$ & $L(\mathrm{~mm})$ & $f_{y}(\mathrm{MPa})$ & $f_{c u}(\mathrm{MPa})$ & $\begin{array}{c}f_{b} \\
(\mathrm{MPa})\end{array}$ & $f_{y v}(\mathrm{MPa})$ & $\rho_{b}$ & $s(\mathrm{~mm})$ \\
\hline A-1 & 426 & 8 & 1300 & 297 & 28.24 & - & - & 0 & - \\
\hline A1-6-1 & 426 & 8 & 1300 & 297 & 28.24 & 414 & 314 & $1.73 \%$ & 100 \\
\hline A1-10-1 & 426 & 8 & 1300 & 297 & 28.24 & 414 & 314 & $2.88 \%$ & 100 \\
\hline A1-10-2 & 426 & 8 & 1300 & 297 & 28.24 & 414 & 314 & $2.88 \%$ & 50 \\
\hline A1-12-1 & 426 & 8 & 1300 & 297 & 28.24 & 414 & 314 & $3.45 \%$ & 100 \\
\hline A2-6-1 & 426 & 8 & 1300 & 297 & 28.24 & 485 & 314 & $1.73 \%$ & 100 \\
\hline A2-10-1 & 426 & 8 & 1300 & 297 & 28.24 & 485 & 314 & $2.88 \%$ & 100 \\
\hline A2-10-2 & 426 & 8 & 1300 & 297 & 28.24 & 485 & 314 & $2.88 \%$ & 50 \\
\hline A2-12-1 & 426 & 8 & 1300 & 297 & 28.24 & 485 & 314 & $3.45 \%$ & 100 \\
\hline A3-6-1 & 426 & 8 & 1300 & 297 & 28.24 & 532 & 314 & $1.73 \%$ & 100 \\
\hline A3-10-1 & 426 & 8 & 1300 & 297 & 28.24 & 532 & 314 & $2.88 \%$ & 100 \\
\hline A3-10-2 & 426 & 8 & 1300 & 297 & 28.24 & 532 & 314 & $2.88 \%$ & 50 \\
\hline A3-12-1 & 426 & 8 & 1300 & 297 & 28.24 & 532 & 314 & $3.45 \%$ & 100 \\
\hline
\end{tabular}


Note: In the table, $D$ is the cross-section diameter of the specimen, $t$ is thickness the steel tube $L$ is the length of members, $f_{y}$ is the yield strength of steel, $f_{c u}$ is the cube crushing strength of concrete, $f_{b}$ is yield strength of the longitudinal reinforcement, $f_{y v}$ is the yield strength of stirrup, $\rho_{b}$ is the ratio of longitudinal reinforcement, $s$ is the stirrup spacing.

\subsubsection{Test procedure}

(1) The test instrument and equipment Axial compression tests were performed in the 1500T hydraulic pressure testing machine, as shown in Figure 12. Collecting device of strains and displacements was DH3816 static strain gauge.

(2)

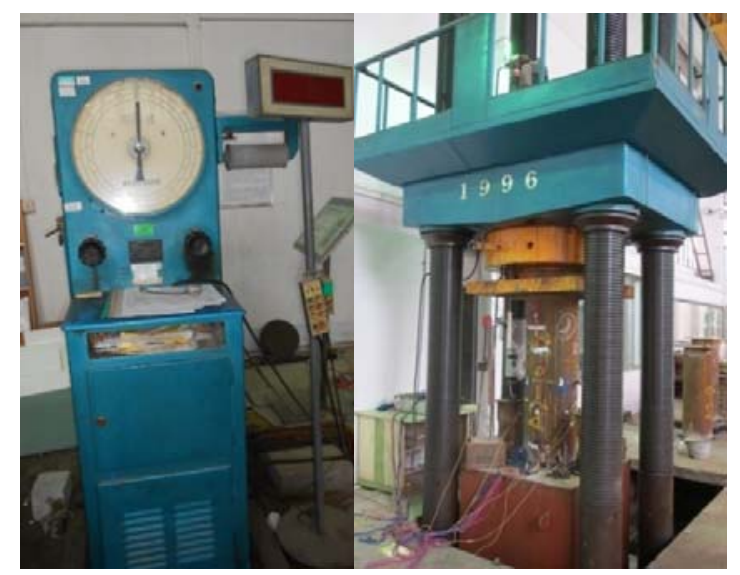

Figure 12. 1500T Hydraulic Pressure Testing Machine

(2) Loading and data acquisition In the axial compression test, the parameters needed to determine were the longitudinal stress-strain relationship of reinforcement, the stress-strain relationship of the steel tube in both the longitudinal and hoop directions. In order to obtain the required parameters, four groups of strain gauges were placed on the middle of the external surface of the steel tube, which were purposed to measure the longitudinal and hoop strains (see Figure 13).

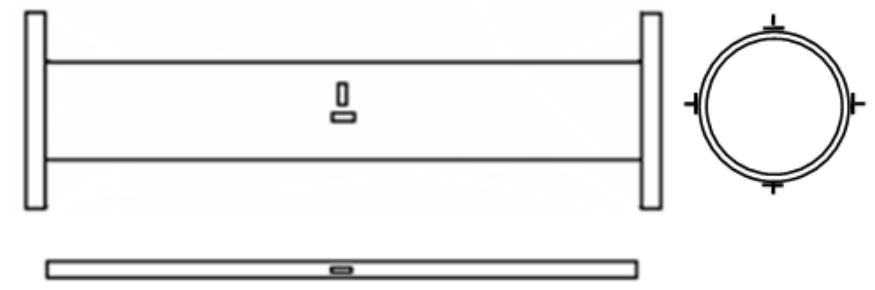

Figure 13. Strain Gauge Arrangement of Steel Tube and Reinforcement

In addition, four internal longitudinal strain gauges were used to measure the axial tension and compression strain of longitudinal reinforcement (Nie et al. [27]). To determine the axial and lateral displacements of the specimens, two axial displacement meters and two lateral displacement meters were placed in the middle of the column (Hou et al. [28]).

\subsection{Experimental Results}

In the axial compression test process, short columns generally do not fall, so when the axial displacement component reaches a certain extent or when the axial deformation is large, the test is stopped or unloaded. 


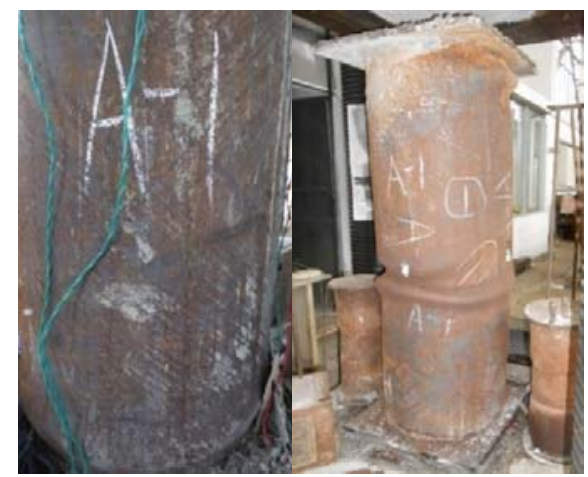

Figure 14. Slip Line and Failure State

The experimental phenomenon (Figure 14) shows that the damage form of RCFST specimens is neither bending failure nor shear failure, but the local buckling. The examination of the internal concrete shows that there is no evidence of debonding from the steel tube although concrete crushing in some places.

A detailed comparison of the theoretical, finite element analysis and experimental results of the short column is given in Table 3. It can be seen from Figure 15 that the ductility of the RCFST members is better than that of CFST members. For such good ductile structural members it is general to take the compressive load at the strain value of 0.0035 as the bearing load of the member (Degtyarev [29]).

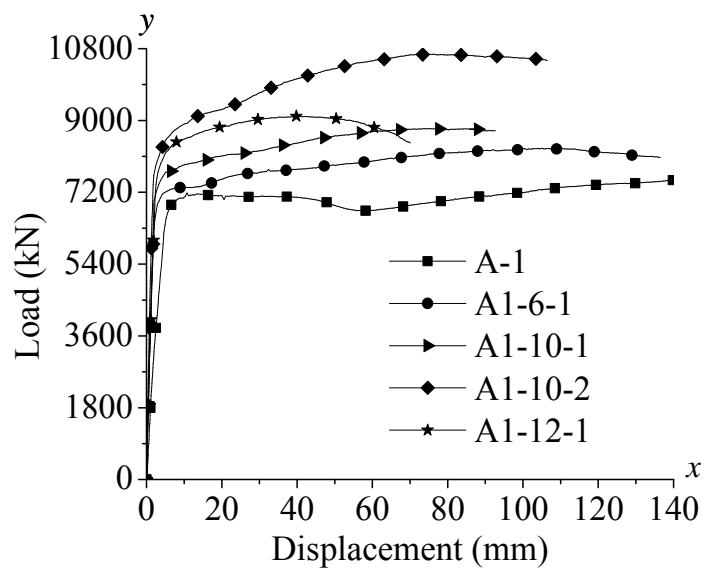

a )The first set of specimens

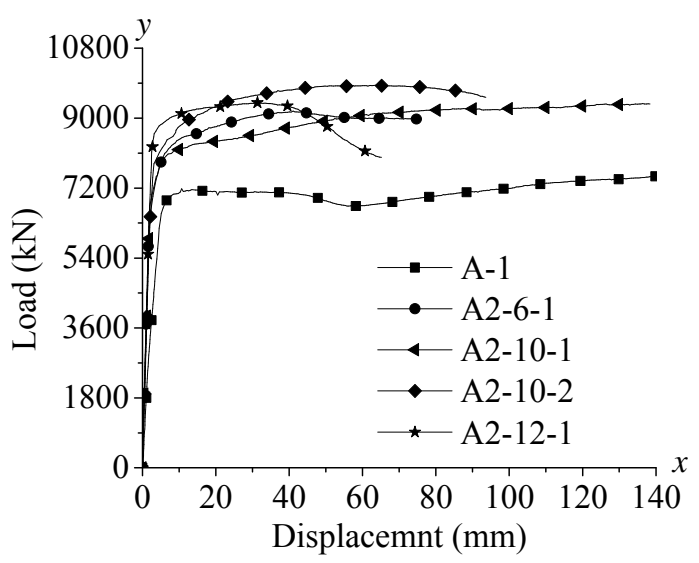

b) The second set of specimens

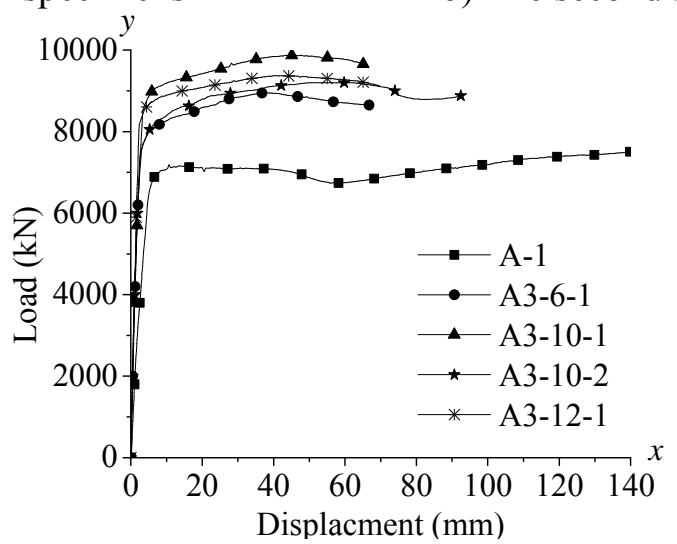

c) The third set of specimens

Figure 15. Loading-displacement Curve of RCFST Short Columns 
Table 3. Axial Compression Bearing Capacity of Short Columns

\begin{tabular}{|c|c|c|c|c|c|}
\hline $\begin{array}{c}\text { Specimen } \\
\text { number }\end{array}$ & $\begin{array}{c}\text { Theoretical } \\
\text { value } N_{c}(\mathrm{kN})\end{array}$ & $\begin{array}{c}\text { Finite element } \\
\text { value } N_{0}(\mathrm{kN})\end{array}$ & $\begin{array}{c}\text { Trial } \\
\text { value } N_{e}(\mathrm{kN})\end{array}$ & $N_{c} / N_{0}$ & $N_{c} / N_{e}$ \\
\hline $\mathrm{A} 1-1$ & 6760 & 6791 & 6826 & 0.996 & 0.990 \\
\hline $\mathrm{A} 1-6-1$ & 8042 & 8045 & 8302 & 1.000 & 0.969 \\
\hline $\mathrm{A} 1-10-1$ & 8637 & 8676 & 8797 & 0.995 & 0.982 \\
\hline $\mathrm{A} 1-10-2$ & 9056 & 9077 & 9946 & 0.998 & 0.911 \\
\hline $\mathrm{A} 1-12-1$ & 8934 & 8999 & 9215 & 0.993 & 0.970 \\
\hline $\mathrm{A} 2-6-1$ & 8204 & 8205 & 8896 & 1.000 & 0.922 \\
\hline $\mathrm{A} 2-10-1$ & 8907 & 8943 & 9375 & 0.996 & 0.950 \\
\hline $\mathrm{A} 2-10-2$ & 9326 & 9344 & 9847 & 0.998 & 0.947 \\
\hline $\mathrm{A} 2-12-1$ & 9258 & 9320 & 9400 & 0.993 & 0.985 \\
\hline $\mathrm{A} 3-6-1$ & 8311 & 8311 & 8748 & 1.000 & 0.950 \\
\hline $\mathrm{A} 3-10-1$ & 9085 & 9118 & 9594 & 0.996 & 0.947 \\
\hline A3-10-2 & 9505 & 9521 & 9388 & 0.998 & 1.012 \\
\hline A3-12-1 & 9473 & 9532 & 9488 & 0.994 & 0.998 \\
\hline \multicolumn{7}{|c|}{ Mean value } & 0.997 & 0.964 \\
\hline
\end{tabular}

\section{CONCLUSIONS}

This paper has presented the theoretical, numerical and experimental investigations on the ultimate bearing load capacity of RCFST columns. The theoretical study is performed by using the combined unified and limit equilibrium theories. The numerical study is done by using the finite element method. The theoretical and FEA results are validated by the experimental data. From the results obtained the following conclusions can be drawn:

1) Addition of longitudinal reinforcement in RCFST short columns can significantly increase the bearing capacity of the columns, in which both longitudinal reinforcement and stirrups play important role in this strength increase.

2) Short columns are neither in bending failure nor in shear failure, but in the local buckling failure of the steel tube.

3) The proposed theoretical formula for calculating the compressive strength of RCFST columns is consistent with existing design code for CFST columns. That is, it reduces to the design formula of CFST when the reinforcement ratio is 0 .

\section{REFERENCES}

[1] Han, L.H. and An, Y.F., "Performance of Concrete-encased CFST Stub Columns under Axial Compression", Journal of Constructional Steel Research, 2014, Vol. 93, pp. 62-76.

[2] Yu, M. at al., "A Unified Formulation for Circle and Polygon Concrete-filled Steel Tube Columns under Axial Compression”, Engineering Structures, 2013, Vol. 49, pp. 1-10.

[3] Dundu, M., "Compressive Strength of Circular Concrete Filled Steel Tube Columns", Thin-Walled Structures, 2012, Vol. 56, pp. 62-70.

[4] Dai, X. and Lam, D., "Numerical Modelling of the Axial Compressive Behaviour of Short concrete-filled Elliptical Steel Columns", Journal of Constructional Steel Research, 2010, Vol. 66, pp. 931-942. 
[5] Yu, T., Hu, Y.M. and Teng, J.G., "FRP-confined Circular Concrete-filled Steel Tubular Columns under Cyclic Axial Compression”, Journal of Constructional Steel Research, 2014, Vol. 94, pp. 33-48.

[6] Prabhu, G.G and Sundarraja, M.C., "Behaviour of Concrete Filled Steel Tubular (CFST) Short Columns Externally Reinforced using CFRP Strips Composite", Construction and Building Materials, 2013, Vol. 47, pp. 1362-1371.

[7] Wang, Y.H., Nie, J.G. and Fan, J.S., "Theoretical Model and Investigation of Concrete Filled Steel Tube Columns under Axial Force-torsion Combined Action", Thin-Walled Structures, 2013, Vol. 69, pp. 1-9.

[8] Ma, H. et al., "Seismic Performance of Steel-reinforced Recycled Concrete Columns under Low Cyclic Loads", Construction and Building Materials, 2013, Vol. 48, pp. 229-237.

[9] Zhong, S.T and Tu, Y.Q., "The Study of Dynamics Behavior of Concrete Filled Steel Tubular (CFST) Members", In Advances in Steel Structures, 1996, pp. 449-454.

[10] Abdalla, S. and Abed, F., "Mohammad AlHamaydeh, Behavior of CFSTs and CCFSTs under Quasi-static Axial Compression”, Journal of Constructional Steel Research, 2013, Vol. 90, pp. 235-244.

[11] GB 50936-2014. Technical Code for Concrete Filled Steel Tubular Structures. (in Chinese)

[12] Liu, S.W., Liu, Y.P. and Chan, S.L., "Advanced Analysis of Hybrid Steel and Concrete Frames, Part 1: Cross-section Analysis Technique and Second-order Analysis”, J. Constr. Steel Res., 2012, Vol. 70, pp. 326-336.

[13] Liu, S.W., Liu, Y.P. and Chan, S.L., "Advanced Analysis of Hybrid Steel and Concrete Frames, Part 2: Refined Plastic Hinge and Advanced Analysis", J. Constr. Steel Res., 2012, Vol. 70, pp. 337-349.

[14] Lie, T.T., "Fire Resistance of Circular Steel Columns Filled with Bar-Reinforced Concrete", Journal of Structure Engineering, 1994, Vol. 120, No. 5, pp. 1489-1509.

[15] Chang, X., Wei, Y.Y. and Yun, Y.C., "Analysis of Steel-reinforced Concrete-filled-steel Tubular (SRCFST) Columns under Cyclic Loading", Construction and Building Materials, 2012, Vol. 28, No. 1, pp. 88-95.

[16] Zhu, M.C., et al., "Experimental Research on Square Steel Tubular Columns Filled with Steel-reinforced Self-consolidating High-strength Concrete under Axial Load", Engineering Structures, 2010, Vol. 32, No. 8, pp. 2278-2286.

[17] Wei, H., et al., "Study on Strength of Reinforced Concrete Flled Circular Steel Tubular Columns", Structural Engineering and Mechanics, 2005, Vol. 19, No. 6, pp. 653-657.

[18] Wang, H.J., et al., "Experimental Study on Twin-column RCFT Pier", Conf. on Advances in Structural Engineering and Mechanics, Busan (Pusan), Korea, 2002.

[19] Endo, T. et al. "Experimental study on reinforced concrete filled steel tubular structure", Conf. on Steel Structures, Singapore, 2000, Proc.7th Int.

[20] Xiamuxi, A. and Hasegawa, A., "A Study on Axial Compressive Behaviors of Reinforced Concrete Filled Tubular Steel Columns", Journal of Constructional Steel Research, 2012, Vol. 76, pp. 144-154.

[21] Slater, W.A., Richart, F.E. and Scofield, G.G., "Tests of Bond Resistance between Concrete and Steel", Journal of the Franklin Institute, Phlebol-Ann Vasc, 1920, Vol. 190, pp. 885-886.

[22] Ludovic, J., et al., "An Elastic Plastic Damage Formulation for Concrete: Application to Elementary Tests and Comparison with an Isotropic Damage Model", Computer Methods in Applied Mechanics and Engineering, 2006, Vol. 195, Issue 52, pp. 7077-7092.

[23] Jeffrey, M., et al., "Reconsidering the Use of High-strength Reinforcement in Concrete Columns", Engineering Structures, 2012, Vol. 37, pp. 135-142.

[24] Lu, Z.H. and Zhao, Y.G., "Suggested empirical models for the axial capacity of circular CFT stub columns", Journal of Constructional Steel Research, 2010, Vol. 66, Issue 6, pp. 850-862. 
[25] Wang, N., Static and Dynamic Performance Research of Bar-reinforce Concrete Filled Steel Tubular Component [D]. 2013, Shenzhen: Harbin Institute of Technology. (in Chinese)

[26] Jamaluddin, N. et al., "An experimental study on elliptical concrete filled columns under axial compression", Journal of Constructional Steel Research, 2013, Vol. 87, pp. 6-16.

[27] Nie, J.G, Wang, Y.H. and Fan, J.S., "Experimental Research on Concrete Filled Steel Tube Columns under Combined Compression-bending-torsion Cyclic Load", Thin-Walled Structures, 2013, Vol. 67, pp. 1-14.

[28] Hou, C., Han, L.H. and Zhao, X.L., "Concrete-filled Circular Steel Tubes Subjected to Local Bearing Force: Experiments", Journal of Constructional Steel Research, 2013, Vol. 83, pp. 90-104.

[29] Degtyarev, V.V., "Strength of Composite Slabs with End Anchorages, Part I: Analytical Model”, Journal of Constructional Steel Research, 2013. 